\title{
Evaluation Structural Strength for Beams and Two-Way Roof Slab Systems using Core Test and load Test and Analyzing the Causes of Their Failure.
}

\author{
Mohammad A. Al Zuhaili ${ }^{1}$, Khalid Y. A. Al Mazrouei ${ }^{2}$ \\ ${ }^{1}$ M.Sc. Civil Engineering, Trainrr of Construction Training Institut, Public Authority of Applied Education and \\ Training, Kuwait, E-mail: ma.alzuhaili@paaet.edu.kw \\ ${ }^{2}$ M.Sc. Civil Engineering, Maneger of Construction Training Institut, Public Authority of \\ Applied \\ Education and Training, Kuwait E-mail:maz.Khalid@gmail.com \\ ملخص: تناقش هذه الورقة اختبار القلب الخرساني واختبار التحميل كطريقة لتقييم القوة الانثائية للنظام الانثائي القائم .

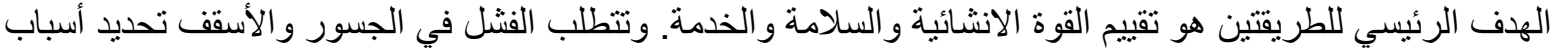

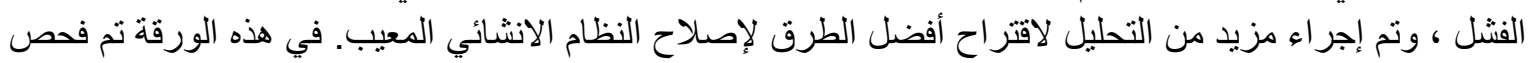

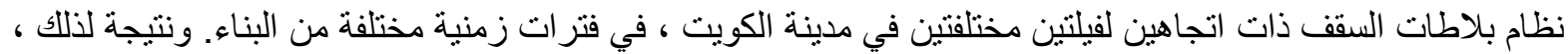

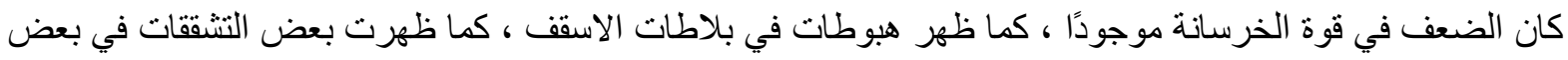

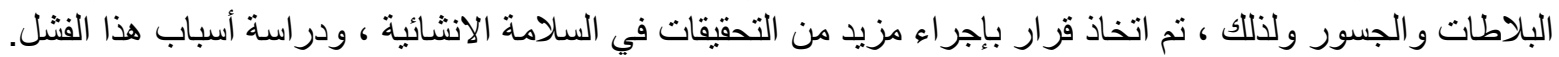

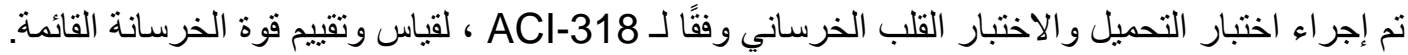

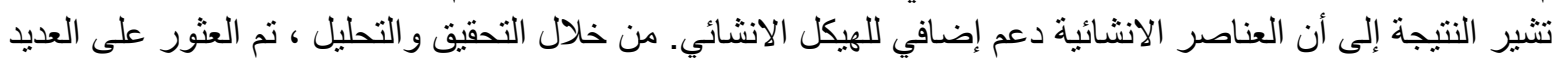 \\ من الأسباب التي تؤدي إلى الفثل في قوة الخرسانة. و أخير ، يتم تقديم توصيات لتقييم سلامة تصميم الهيكل.
}

Abstract: This paper discusses Core Test and Load Test as a method to evaluate Structural Strength for existing structural system. The primary objective of the two methods is to assess structural strength, safety and serviceability. Failure in beams and roof Slabs structural strength were targeted to determine the causes of the failure, and further analysis has been done to suggest the best methods to repair the defected structural system. In this paper a two-way roof slab system for two different vacant villas in Kuwait City was inspected, at different construction time intervals. As a result, weakness in concrete strength was present, and a deflection appears in roof slabs, also cracks appeared in some of slabs and beams. Therefore, decision was made to do further structural safety investigation, and study the causes of such failure. Load test and core test according to $\mathrm{ACl}-318$, were carried out to measure and evaluate the strength of the existing concrete. The result indicates that the structural elements is unsafe, so a necessitate procedure should be carried-out to support these elements, like re-design, recasting, adding additional structure support. Through investigation and analysis, several reasons were found that leads for failure in concrete strength. Finally, recommendations to assess the safety of the structure design is given.

Keyword: Concrete structure; Field test; Load test; Core test; In situ test; Two-way slab system.

\section{1) Introduction}

Structure concrete member, designed to resist different applied forces. Where the compressive strength value for that member indicates concrete properties. Standard test specimens (according to standard specifications and codes) are examined during construction, to ensure concrete quality and potential strength. Repeated arguments in whether the specimens standard test can represent in-situ strength of concrete, 
especially when the specimens result indicates noncompliance with the specification. In such cases, a complicated problem is generated and immense argue will present, as the conflict between the two parties (Contractor, Engineer consultancy Office) can end up in worse positions than when they started the investigation. Compressive concrete strength test is done by drilling cylinder specimens from suspected structural member, then sent to a specialized laboratory to determine the compressive strength, it is very useful to get result from different kind of tests. Core test is the most popular way to assess the properties of the concrete in the structure [1]. The test result will be shown as a PSI Number, that must be processed, and the strength value should be cautiously interpreted, because core strengths are affected by a number of factors such as diameter, $\mathrm{l} / \mathrm{d}$ ratio and moisture condition of the core specimen, the direction of drilling, the presence of reinforcement steel bars in the specimen and the strength level of the concrete [4]. From general prospective, core test is ultimately needed to assess the following:

1. Concrete potential strength.

2. Concrete actual strength.

3. Structure member capacity load design, actual loads and new additional load.

4. Structure deterioration factors like fatigue, chemical reaction, fire, and explosion.

\section{2) Literature survey:}

Core testing and Load testing of concrete structures in the United States is a century old tradition with one of the earliest well-documented cases are found in the 1890 s Birkmire 1894 [6] [7].

The American Concrete Institute began formalizing load test for concrete structures in 1920 [8] ACl [9]. At that time, the evaluation criteria for passing the load test focused on maximum deflection under sustained load combined with the recovery of deflection after the test load removed. Subsequent Codes ACl 1936 defined the deflection evaluation criterion as a function of the span length squared and divided by the total depth of the member cross section [1]. This form of the deflection criterion is still in effect $\mathrm{ACl} 2005$. Notable investigations into load testing of concrete structures are documenting the practice of the last decades can be found in the literature Fitz Simons and Longinow 1975; RILEM 1984; Bungey 1989.[1],[10],[11],[12], [13]

\section{3) Case Study:}

In this research a site evaluation preformed on two-way solid roof slabs for two villas, to identify the load level for each structure and causes of failure, with consideration to the design and Implementation of Load Test and Core Test, also its focuses on evaluation criteria and their significance, limitations and applicability. Those structure elements were chosen carefully to represent an ideal case study. Site evaluation shows a deflection in the center and diffuse cracks in top and Bottom faces of slabs, the slabs dimension is $(6.90 \mathrm{~m} \times 5.25 \mathrm{~m}, 6.00 \mathrm{~m} \times 6.20 \mathrm{~m})$ and it supported by beams $(6.00 \mathrm{~m} \times$ $5.00 \mathrm{~m})$.

The following summarizes the preliminary assessment of the structure and the sources for the information used in designing the core test and load test.

\section{First Case:}

\section{General description of the building:}

A typical concrete frame and brick walls house, consists of basement, ground, $1^{\text {st }}$ and $2^{\text {nd }}$ floor. The building was constructed in conventional method, built from reinforcement concrete and the cement block walls (Figure 1, 2, 3). This study is carried out to assess the 
integrity of the Structural system of an existing building in Bayan area. An architectural, structural drawings, and data available, as well results of concrete core tests.

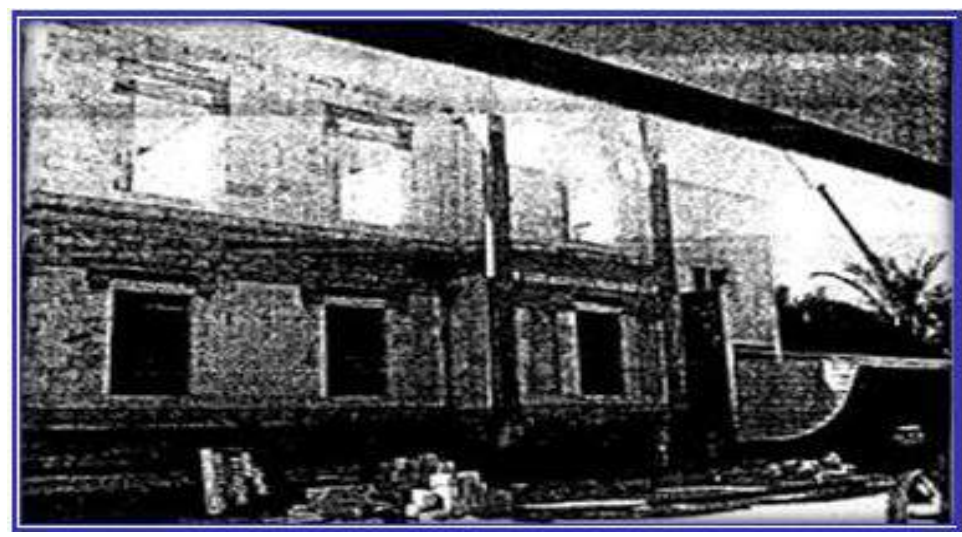

Figure 1 General view of the building

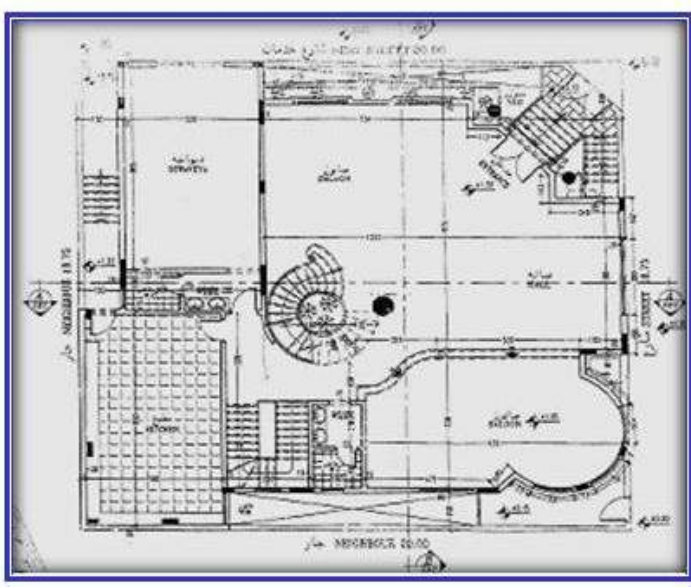

Figure 2 Ground floor plan

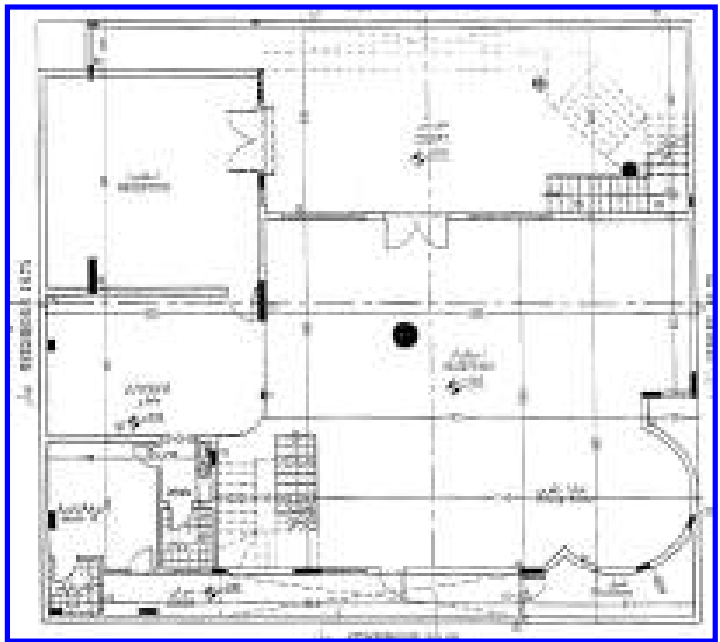

Figure 3 basement floor plane

\section{Optical inspection results}

The cracks distributed at the positive and negative moment regions, and deflection in center of slabs. Core test carried out of slabs and beam for assess the strength of the existing concrete and look for reasons If its fail. A detailed optical inspection was carried out to identify the apparent structural defects, and to compare between the actual structural elements dimensions executed on site, and the design dimensions on the drawings. Some information was gathered as follow:

- Inclined cracks in some beams type B17, CB1and CB5 in the ground roof.

- Cracks in some slabs, at the bottom in the ground roof (Figure 4).

- Changes in the color of the concrete slab roof in various places (Figure 5)

- Vertical cracks in beam B3 (Figure 6).

Concrete core samples were taken from various parts of the building. The results show concrete compressive strength for beam CB5 is $130 \mathrm{~kg} / \mathrm{cm} 2$, for beam B18 is $140 \mathrm{~kg} / \mathrm{cm} 2$, and for the ground floor roof is $168 \mathrm{~kg} / \mathrm{cm} 2$. The results indicate a weak concrete. 


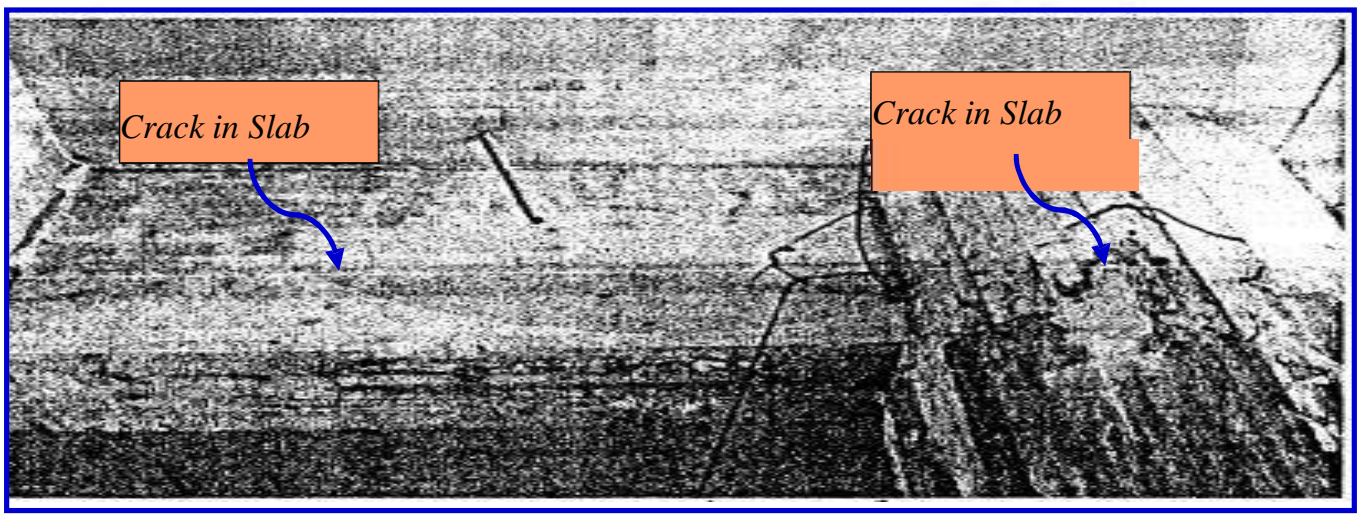

Figure 4 Cracks at the bottom of the slabs
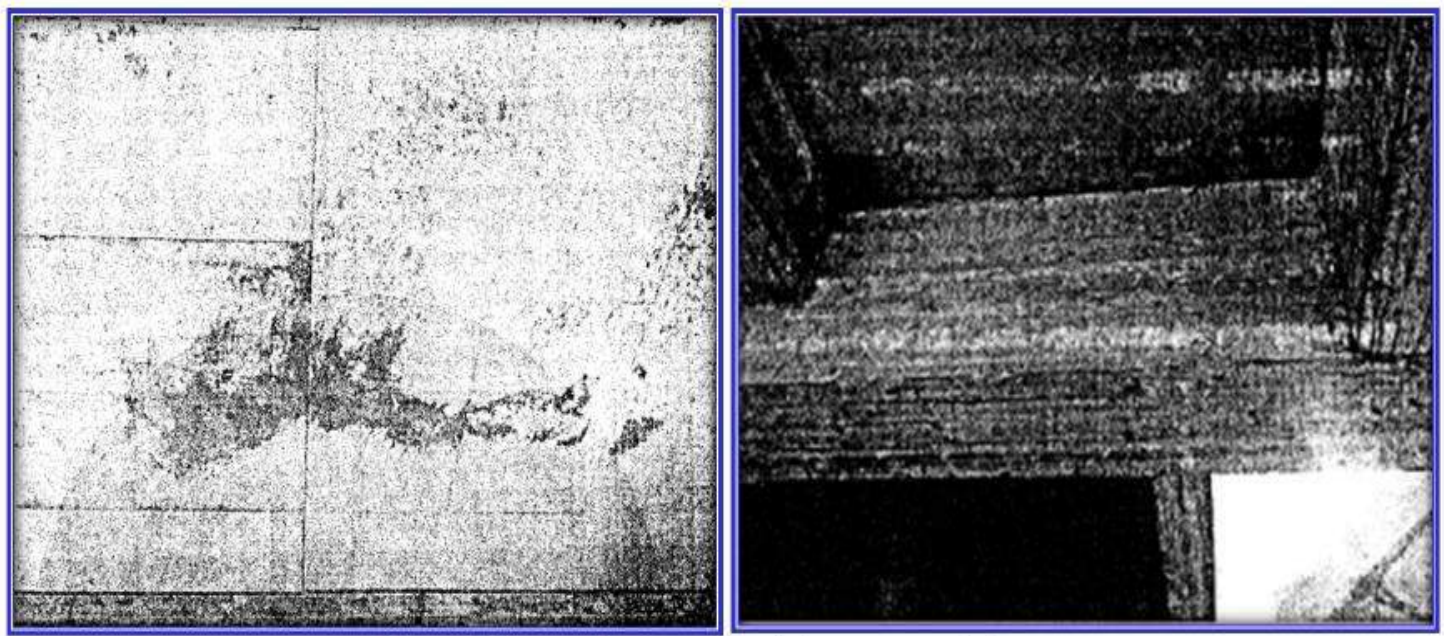

Fiqure 5 Chanqes in the color of the concrete slab
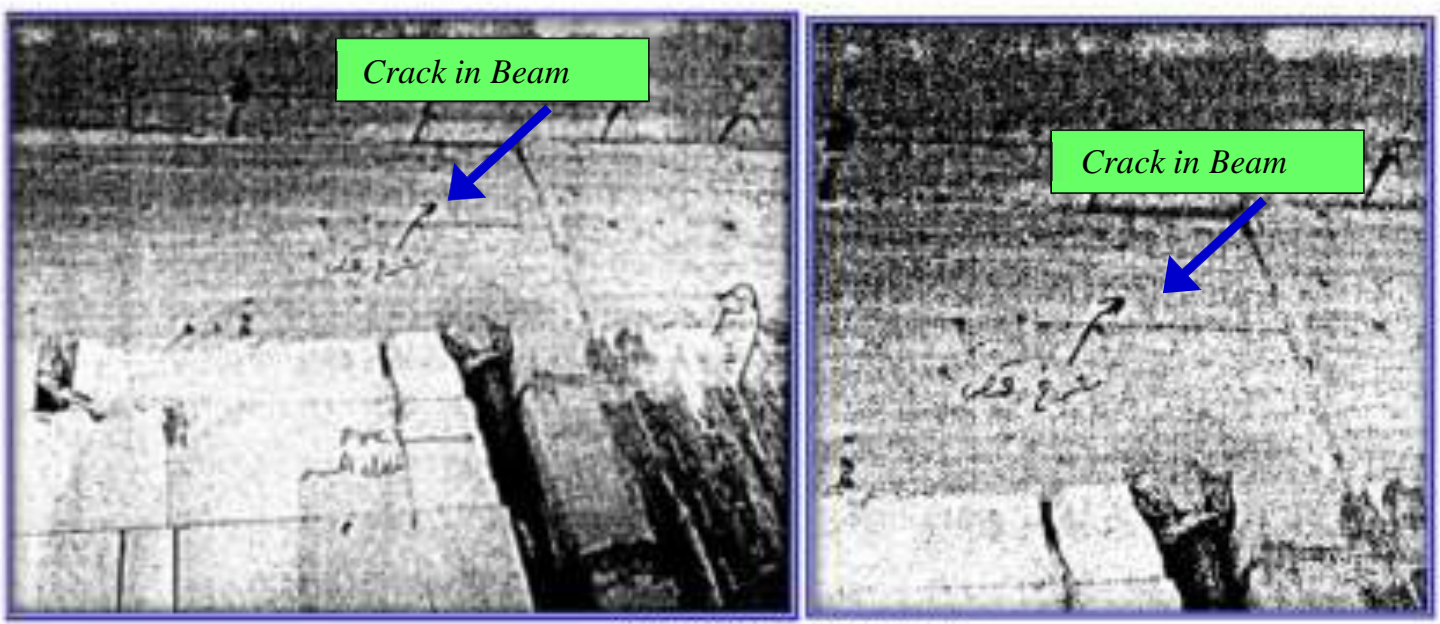

Figure 6 Cracks in the beams 


\section{Concrete tests}

According to chapter 5.6.5.4. of ACl-318 specifications as follows: Concrete is considered as constructively valid if the core test samples are provided with the following two conditions:

- The strength average of three samples not less than $85 \%$ of concrete strength design.

- No sample presented with strength less than $75 \%$ of concrete strength design.

Five concrete samples core was taken from various places in the building ( 3 samples from the beams and 2 from the ground roof slab) to determine the concrete's ability to bearing the compressive strength of concrete and its quality. And for measure the actual strength of the concrete. They were examined after 24 hours from extraction. The following table shows the detailed results of concrete samples (Figure 7, 8, Table 1)
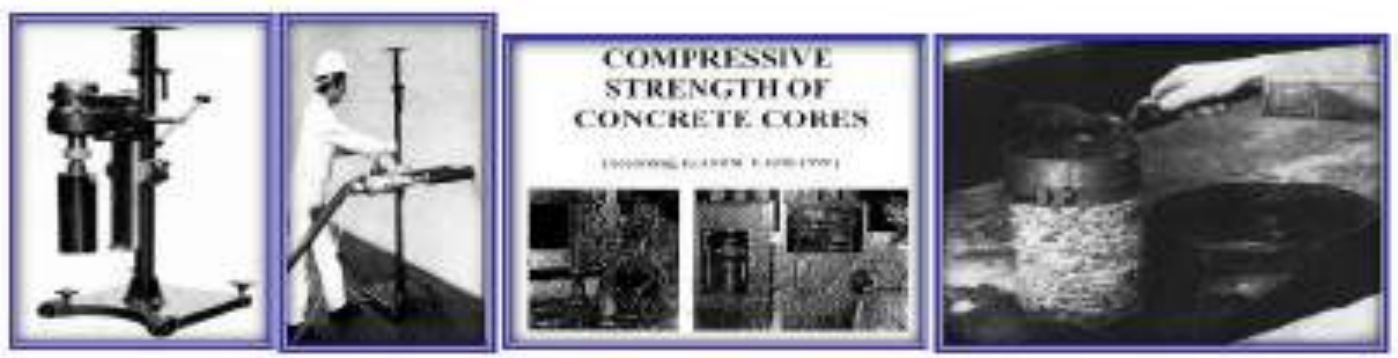

Figure 7 instruments of concrete core test (according to ASTM C42M-1999),

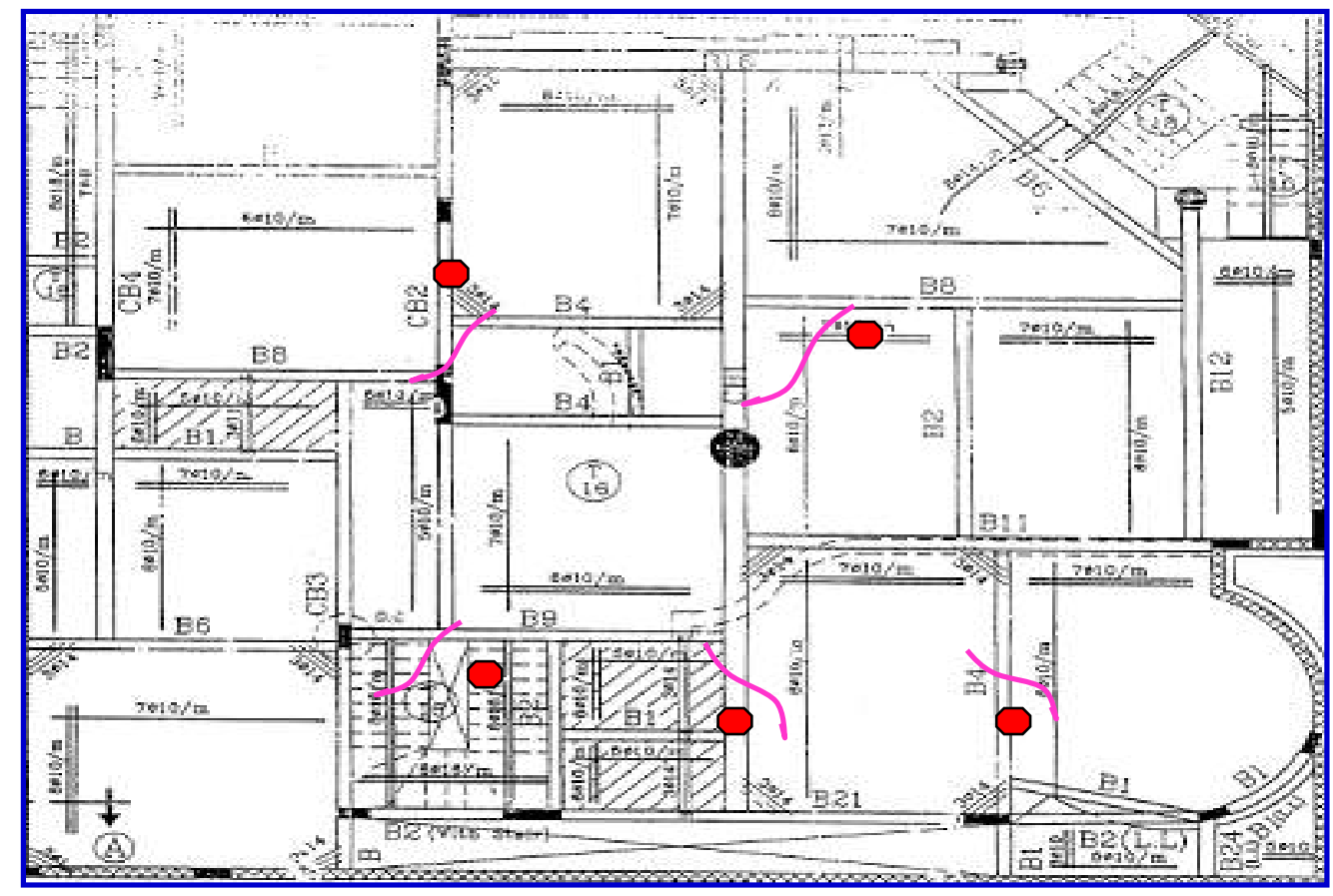

Figure 8 Location of core test \& Crack in Slab

\section{Concrete compressive strength:}

The specifications of the building stipulate that the compressive strength of concrete for the slabs and beams should be not less than $250 \mathrm{~kg} / \mathrm{cm} 2$ and columns $300 \mathrm{~kg} / \mathrm{cm} 2$.

The results were $208,130,205 \mathrm{~kg} / \mathrm{cm} 2$ in the beams and $168,170 \mathrm{~kg} / \mathrm{cm} 2$ in the slab. 
Samples CB3 and GS1 contain bars of reinforcement, which significantly affect the result, and should be taken into consideration when using it in structural analysis. The strength of GB2 beam decreases to $130 \mathrm{~kg} / \mathrm{cm} 2$, about $52 \%$ of the required strength (Table 1,2). The results show that the average strength of the beam and slabs samples is $188 \mathrm{~kg} / \mathrm{cm} 2$, which is equivalent to $75 \%$ of the imposed design strength of $250 \mathrm{~kg} / \mathrm{cm}^{2}$. It is also noted that three samples are less than $75 \%$ of the design strength imposed (Table $1,2,3$ )

Table 1. Results of core test from INCO-LAB, KWAIT

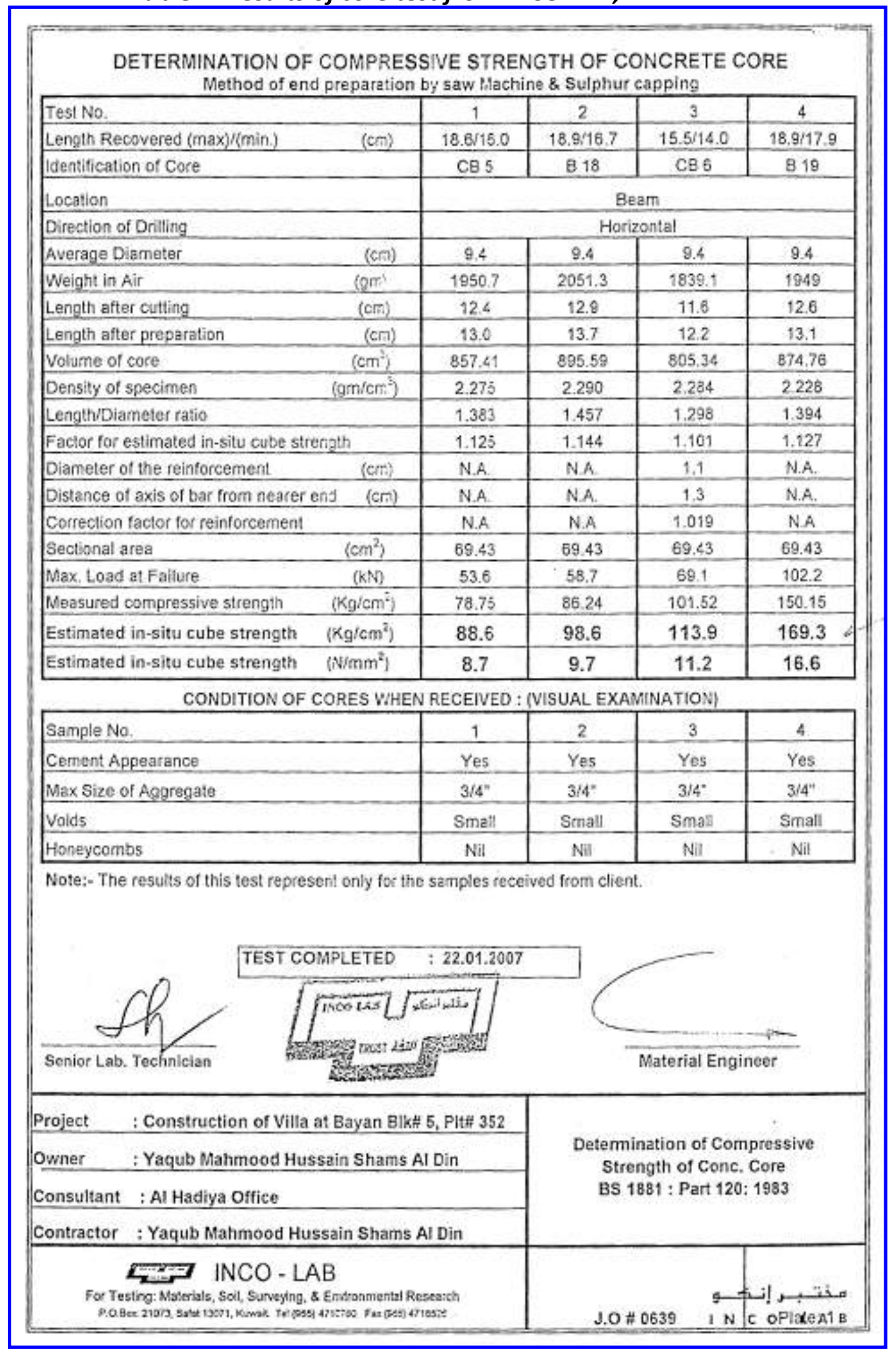


Table 2. Results of core test

\begin{tabular}{|c|c|c|c|c|c|}
\hline & Specimen & $B C 1$ & GC1 & $F C-1$ & GS-2 \\
\hline 1 & - Identification of the specimen: & \multicolumn{4}{|c|}{ Beam } \\
\hline 2 & - Location: Axes & CB5 & B18 & CB6 & B19 \\
\hline 3 & - Average diameter (cm): & 9.4 & 9.4 & 9.4 & 9.4 \\
\hline 4 & - Weight in Air (gm) & 1950.7 & 2051.3 & 1839.1 & 1949 \\
\hline 5 & -Volume of core & 857.41 & 895.59 & 805.34 & 874.76 \\
\hline 6 & - Density of specimen $(\mathrm{kg} / \mathrm{m} 2)$ & 2.275 & 2.290 & 2.284 & 2.228 \\
\hline 7 & -Factor for estimated in situ cube strength & 1.1 .25 & 1.144 & 1.101 & 1.127 \\
\hline 8 & - Sectional area $(\mathrm{cm} 2)$ & 69.43 & 69.43 & 69.43 & 69.43 \\
\hline 9 & - Maximum load of failure (KN) & 53.6 & 58.7 & 69.1 & 102.2 \\
\hline 10 & -Measured compressive strength & 78.75 & 86.24 & 101.52 & 150.15 \\
\hline 11 & -Estimated in-situ cube strength $\left(\mathrm{N} / \mathrm{mm}^{2}\right)$ & 8.7 & 9.7 & 11.2 & 16.6 \\
\hline 12 & - Estimated insitu cube strength ( $\mathrm{kg} / \mathrm{cm} 2)$ & 88.6 & 98.6 & 113.9 & 169.3 \\
\hline
\end{tabular}

Table 1. Results of core test

Tests results indicate that ground roof slab design didn't met the code $\mathrm{ACl}-318$. Also, the concrete mixture test result show weakness in concrete strength, due to failure in water percentage in the mixture. It is necessary to verify the slabs in other ways as a load test (Figure 9).

Table 3. Analysis of core test results

\begin{tabular}{|c|l|c|c|c|c|}
\hline No & -Strength of core test $\left(\mathrm{kg} / \mathrm{cm}^{2}\right)$ & BC1 & GC1 & FC-1 & GS-2 \\
\hline 1 & -Strength design value & \multicolumn{3}{|c|}{250} \\
\hline 2 & -Min. Computing $=0.85^{*} F C$ & \multicolumn{3}{|c|}{212.5} \\
\hline 3 & -Average Strength & \multicolumn{3}{|c|}{$\underline{117.6}$} \\
\hline 4 & -Strength Not Less Than0.75* FC & \multicolumn{3}{|c|}{187.5} \\
\cline { 2 - 5 } 5 & -Test Reading (insitu) & 88.6 & 98.6 & 113.9 & 169.3 \\
\hline 6 & -Result & Unverified & Unverified & Unverified & Unverified \\
\hline
\end{tabular}

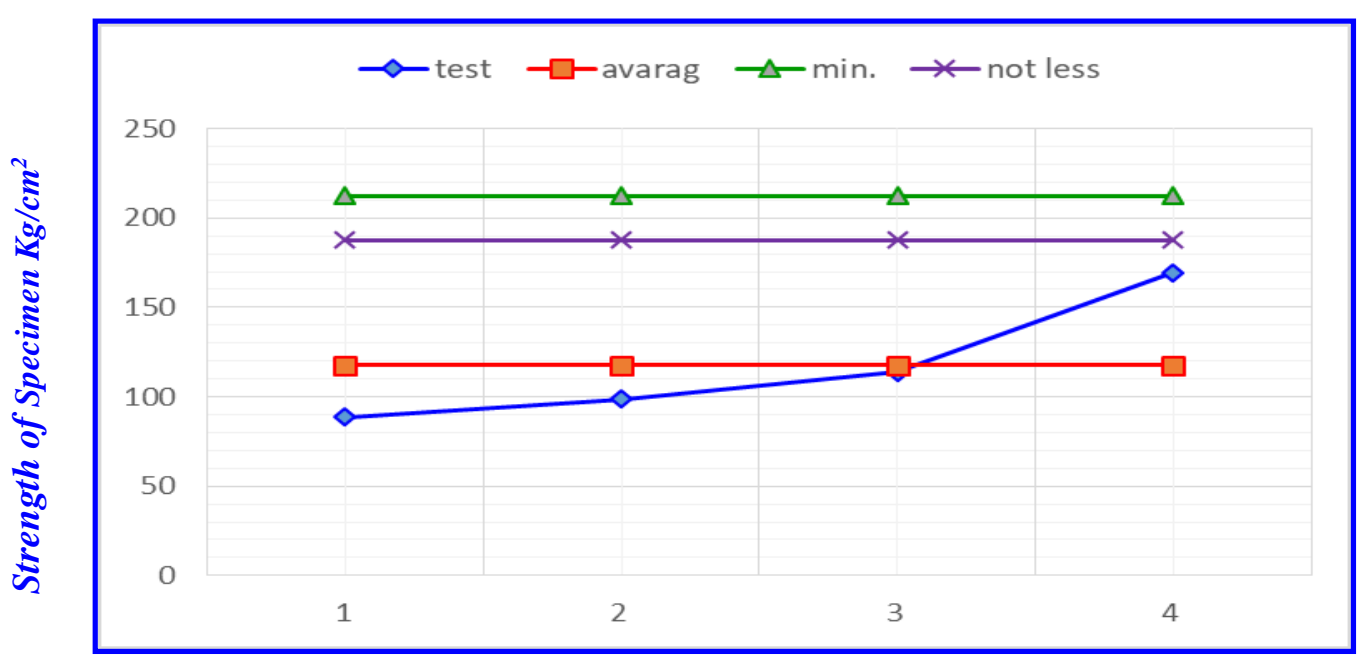

Number of Specimen

Figure 9 Strength of core test, average, min., not less 


\section{Study and Analysis:}

It is clear from the study that the thickness of the slabs is insufficient as well as the reinforcing steel in both directions. Absence of upper reinforcement steel, resulting in cracks around the slabs and the sides of the beams, as there is no reinforcing in the corners of the slabs causing additional cracks. The reduction of the cross-sectional reinforcing steel in the B11 and the CB5 beam was also shown to be unsafe due to the design and the weakness of the concrete, resulting in clear cracks. It is noted from the design that the slabs are designed as simple support and should be designed as continuous slabs with the knowledge that the reinforcing steel is properly positioned and properly designed. The upper reinforcing steel was not extended to $22 \%$ of the larger beam's length in the adjacent beam, which is failure to follow $\mathrm{ACl}-318$ design code.

\section{First case analysis:}

The study shows that the structural elements in the building need supporting and strengthening to enable the building to carry out the structural role required to ensure the structural safety required for the building: The repair process should be designed for defective structural elements by a consulting engineering firm specializing in repairs Beams and slabs in which a landing by a specialized company and engineering supervision should be repaired.

\section{Second Case:}

\section{General description of the building:}

The study was conducted for an existing building (villa) in the Salmiya area. The information and data available are architectural and structural drawings, as well as the results of concrete core tests and load test.

The building consists of a basement, ground, first, second floors, and a roof with two rooms. The building was constructed as the structure shown (Figure 10)

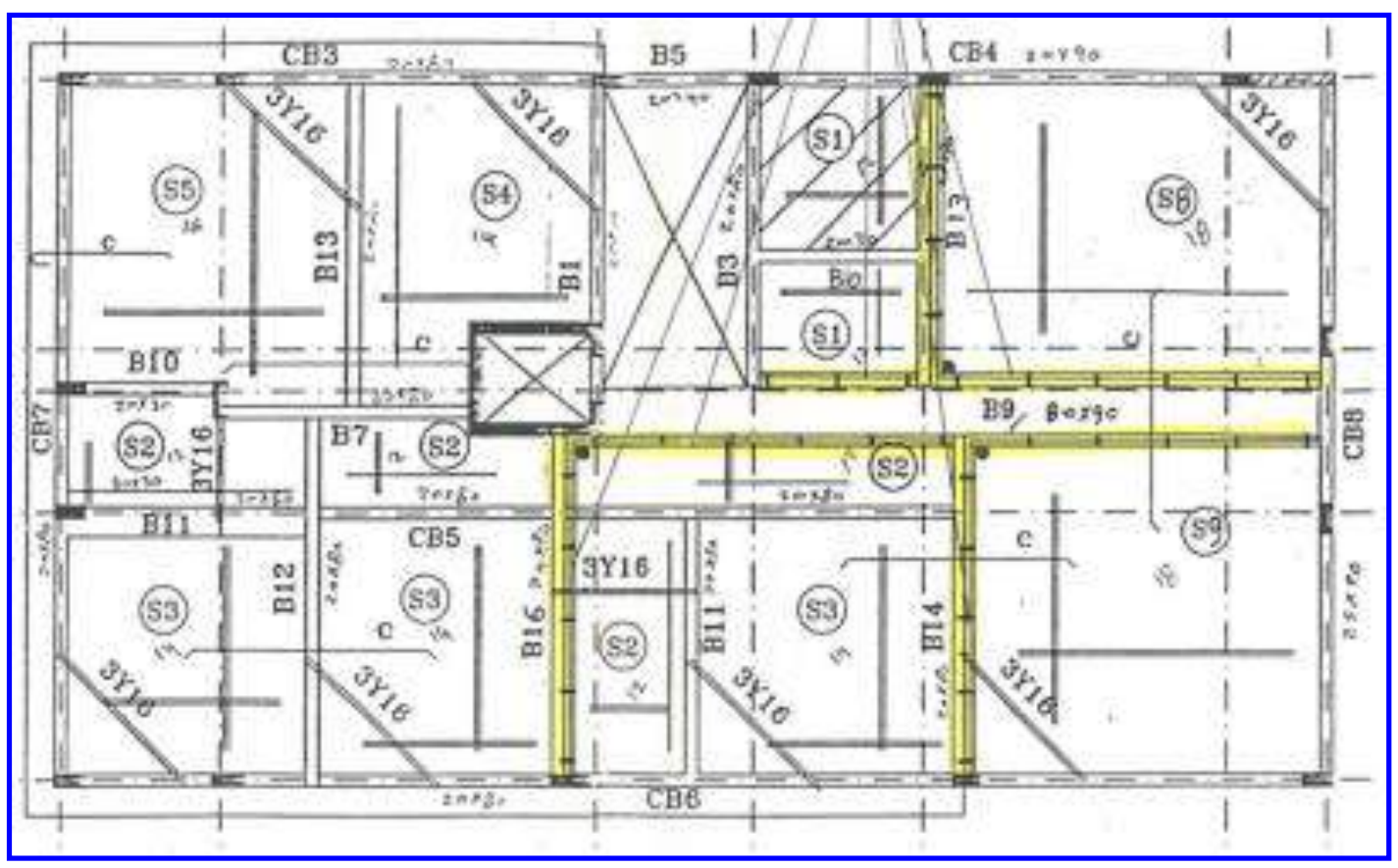

Figure 10 first floor roof slabs plan 


\section{Optical inspection results:}

From the observation and visual inspection of the building, there are many damages and defects in structural elements:

\subsection{Beams:}

1.1.1. The air conditioning duct openings are near the beams support points (at the high shear points), causing fractures and cracks in these places. (Figure 11).

1.1.2. The concrete cover of the steel reinforcing of the beams is insufficient as the stirrups steel reinforcing have appeared from the bottom of the beam.

1.1.3. There are cracks around most of the air conditioning duct openings in the beams.

1.1.4. Nesting and voids (honey comb) in concrete

1.1.5. Adhesion the bars of steel reinforcing in some beams, which prevents the passage of concrete, causing a lack of cohesion between concrete and steel

1.1.6. There are inclined in some beams and lack of straightness (Figure 11)

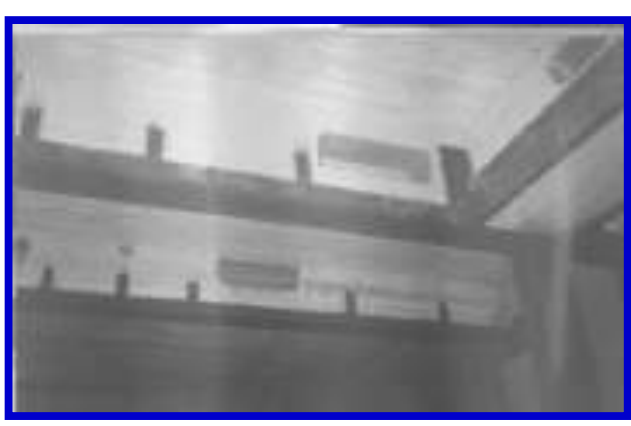

Core Location

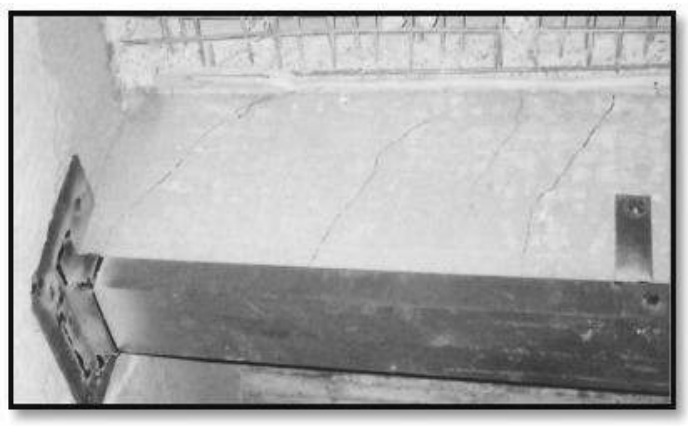

Crack in beam

Figure 11 Core Location \& Cracks in beams

\subsection{Slabs:}

1.2.1. The presence of water in many areas in most of the slabs, indicating the presence of cracks and deep fractures on the whole thickness of the slab

1.2.2. There are cracks and cracks up in some places to display $2 \mathrm{~mm}$

1.2.3. There is a large deflection in the floors of the first floor (roof of the ground floor) up to $5 \mathrm{~cm}$ in slabs S5, S8 and S9 in addition to the presence of deep and many cracks on the perimeter of the slab sometimes reach the full thickness of the slab (Figure 12)
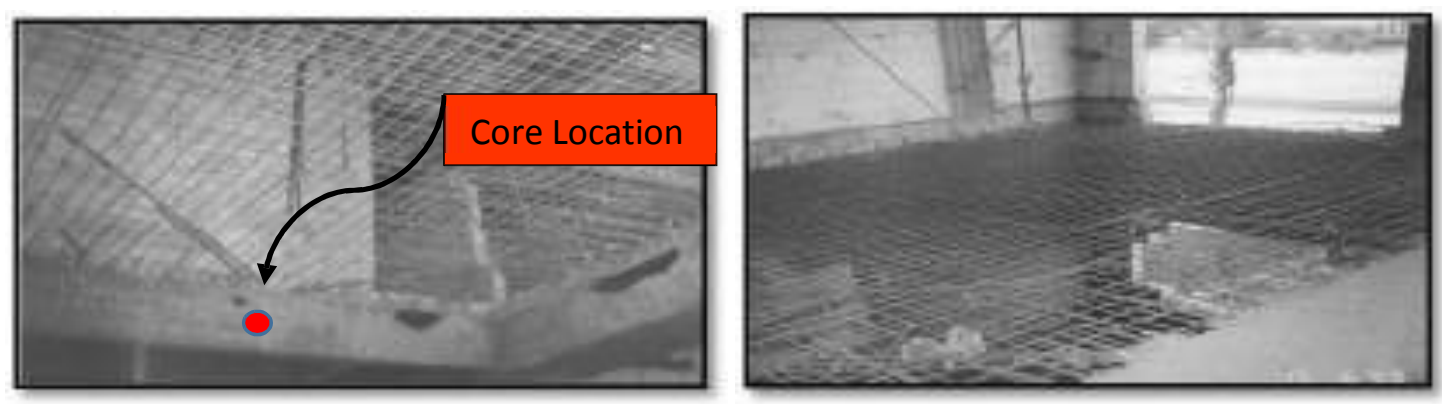

Figure 12 Slabs S9, S8 after demolishing 


\section{Core test:}

10 concrete core test samples were taken from all parts of the building to verify the quality and safety of the concrete in all floors, taking into consideration that they are distributed so that each floor and all structural elements are represented, and the following table shows in Table $(4,5)$

Table 4. Results of core test from MPW, KWAIT $\left(\mathrm{N} / \mathrm{mm}^{2}\right)$

\begin{tabular}{|c|c|c|c|c|}
\hline 21.2 & 15.9 & 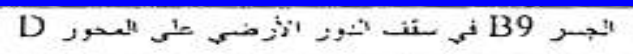 & B6 & 9 \\
\hline 21.2 & 17.5 & 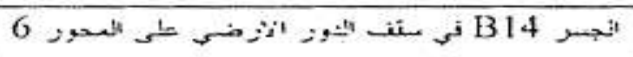 & B7 & 10 \\
\hline 21.2 & 18.3 & B- & S8 & 11 \\
\hline 21.2 & 17.1 & 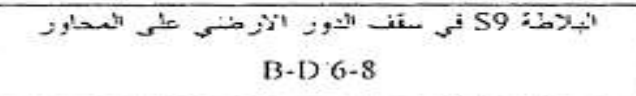 & S9 & 12 \\
\hline 21.2 & 16.9 & 散 & S10 & 13 \\
\hline 21.2 & 22.1 & 1\%/5; & $\mathrm{C} 11$ & 14 \\
\hline 21.2 & 13.1 & 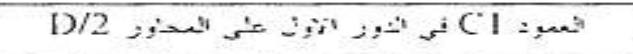 & $\mathrm{C} 22$ & 15 \\
\hline 21.2 & 13.3 & 13/6 & $\mathrm{C} 23$ & 16 \\
\hline 21.2 & 22.8 & D & 1312 & 17 \\
\hline 21.2 & 17.1 & 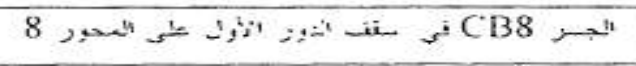 & B 313 & 18 \\
\hline 21.2 & 13.9 & 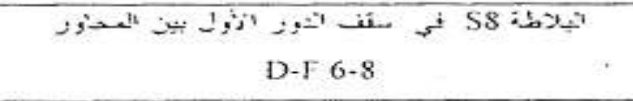 & $\mathrm{S14}$ & 19 \\
\hline 21.2 & 11,1 & 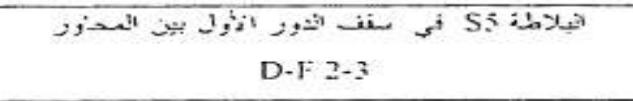 & $\mathrm{S} 15$ & 20 \\
\hline
\end{tabular}

Table 5: results of core test

\begin{tabular}{|c|c|c|c|c|c|c|}
\hline No. & & Location of the specimen & Identification & Number & Cubic Strgh $\left.\mathbf{~} \mathbf{k g} / \mathbf{c m}^{2}\right)$ & Result \\
\hline 1 & 9 & Ground slab roof & Beam & B9 & $\underline{\mathbf{1 8 7}}$ & Unverified \\
\hline 2 & 10 & Ground slab roof & Beam & B14 & 206 & Verified \\
\hline 3 & 11 & Ground slab roof & Slab & S3 & 215 & Verified \\
4 & 12 & Ground slab roof & Slab & S9 & 202 & Verified \\
\hline 5 & 13 & Ground slab roof & Slab & S5 & 199 & Verified \\
6 & 15 & First slab roof & column & C11 & $\underline{\mathbf{1 5 5}}$ & Unverified \\
\hline 7 & 16 & First slab roof & column & C5 & $\underline{\mathbf{1 5 6}}$ & Unverified \\
\hline 8 & 18 & First slab roof & Slab & S9 & $\underline{201}$ & Verified \\
\hline 9 & 19 & First slab roof & Slab & S8 & $\underline{\mathbf{1 6 4}}$ & Unverified \\
\hline 10 & 20 & First slab roof & Slab & S5 & $\underline{\mathbf{1 5 0}}$ & Unverified \\
\hline
\end{tabular}

2.1. Measuring the actual thickness of the slabs

The actual thickness of the slabs that were taken from the core test specimen was measured and compared with the design thickness. The following (table 6) shows the actual thickness and the thickness of the design:

Table 6. Actual thickness of the slabs

\begin{tabular}{|c|c|c|c|c|}
\hline No & specimen & slab & design thickness $(\mathbf{c m})$ & actual thickness (cm) \\
\hline 1 & S3 & S3 & 14 & 15 \\
\hline 2 & S9 & S9 & 18 & 13 \\
3 & S10 & S5 & 16 & 13.5 \\
4 & S18 & S9 & 18 & 15 \\
\hline 5 & S14 & S8 & 18 & 15 \\
\hline 6 & S15 & S5 & 16 & 13.5 \\
\hline
\end{tabular}

84 / 15 


\subsection{Concrete strength of core tests}

According to the data above and to chapter 5.6.5.4. Of ACl-318 specifications conditions for concrete core tests, it can be concluded as following:

2.2.1. In basement, the average concrete strength of the slab is $67.2 \%$ of the design value. In some area the concrete strength value as low as $59 \%$ of the design value, which considered a failure in the concrete slab.

2.2.2. In ground floor, the average concrete strength of the slab is less than $82 \%$ of the design value, which considered a failure in the concrete slab.

2.2.3. In first floor, the average concrete strength for the slab is equivalent $76.4 \%$ of the design value. In some area the concrete strength value is $52 \%$ of the design value, which considered a failure in the concrete slab. The thickness of roof slabs was measured in the concrete core test samples and compared with the design thickness according to the drawings and it was found $10 \%$ less.

\subsection{Study and Analysis:}

By comparing structural analysis of the core test results with the structural design provided by the Engineering Consulting Office, it can be concluded as following:

2.3.1. Beams: The reinforcement ratio of some beams is greater than the permissible, reinforcement ratio according to $\mathrm{ACl}-318$, which makes the method of failure surprising (Brittle mode of failure) in the case of increasing the stresses of what the structural elements

2.3.2. Slabs: In the ground and first floor the slabs $(\mathrm{S} 5, \mathrm{~S} 8, \mathrm{S9})$ are unsafe structure. Table $(5,7)$, Figure 13

\section{Table 7. Analysis of results core test}

\begin{tabular}{|c|c|c|c|c|c|c|c|c|c|c|c|}
\hline & specimen & B9 & B14 & S3 & S9 & S5 & C11 & C5 & S9 & 58 & S5 \\
\hline 1 & Strength design value & \multicolumn{10}{|c|}{250} \\
\hline 2 & Min. Computing $=0.85^{*} \mathrm{FC}$ & \multicolumn{10}{|c|}{212.5} \\
\hline 3 & Average Strength & \multicolumn{10}{|c|}{$\underline{183.5}$} \\
\hline 4 & Strength Not Less Than $0.75^{*} \mathrm{FC}$ & \multicolumn{10}{|c|}{187.5} \\
\hline \multirow[t]{2}{*}{5} & Test Reading (in-situ) & 187 & 206 & 215 & 202 & 199 & $\underline{155}$ & $\underline{156}$ & 201 & $\underline{164}$ & $\underline{150}$ \\
\hline & Result & \multicolumn{10}{|c|}{ UnverVerifie Verifi Verifi Verifi Unver UnverVerifie Unver Unver } \\
\hline
\end{tabular}

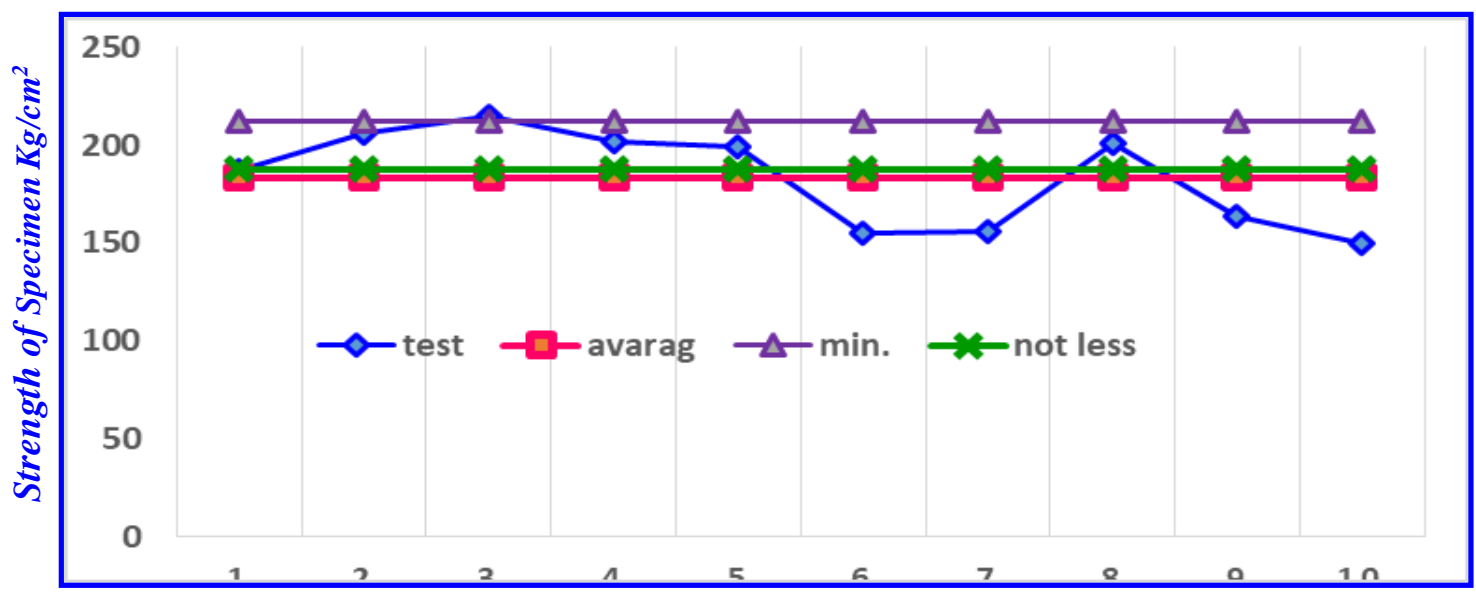

Number of Specimen

Figure 13 Strength of core test, average, min., not less 


\section{Load Test:}

\subsection{Testing Procedure:}

The next section shows the conceptual steps followed to:

- Determine the value of the total test load magnitude during a preparatory phase.

- Obtain the continuous structural assessment, during the load test performance.

- Obtain the real-time calibration of the test load according to the continuous assessment of the boundary conditions through the measurement of selected structural parameters.

3.1.1. Applying load Intensity test levels as recommended in Chapter 20 of ACl-318

3.1.2. Applying Load Test Protocols as recommended ACl standard, two variables are considered for the principle evaluation:

- Dead load effect.

- Live load effect.

Total load (weight) applied on the tested deck slab calculated as recommended in $\mathrm{ACl}-318 / 318 \mathrm{R}$ [17], [18].

The Value test load shall be calculated as follow

$$
\text { Test load W }=0.85 \times(1.4 \mathrm{D}+1.7 \times \mathrm{L})
$$

\subsubsection{Load Configuration}

The load was distributed uniformly on the three floor slabs, measurement came the exact as in load testing resulting from factored uniformly-distributed load, in terms of negative moment.

The $\mathrm{ACl}$ requirements and standards for the structural using condition must be considered and limited by two variables that are [16],[17],[18]:

- Maximum Deflection and.

- Rebound Deflection or Residual Deflection.

According to $\mathrm{ACl} 318 / 318 \mathrm{R}$, the maximum deflection and the rebound deflection are
$\Delta \max \leq \mathrm{L} 2 / 20000 \mathrm{~h}$
(2)
$\Delta$ rebound $\leq \Delta \max / 4$

Where: $\Delta$ max is the maximum deflection

$\Delta$ rebound is the rebound deflection or Residual Deflection

$L$ is length of slab on the short side, and $h$ is thickness of slab

\subsubsection{Load Testing Procedure}

$>$ Dial gauges with magnetic base, installs into the slab structure in several points, where dial gage no.3 (G1) is installed at the middle of the slab. (Figure 13).

$>$ Initial deflections, and temperature prior the testing should be recorded.

$>\quad$ Load should be increased gradually $(0 \%-25 \%-50 \%-75 \%-100 \%)$ of the maximum load, while each load stage held for 1 hour, and for the maximum load (100\%) it should held for 24 hours.

$>$ After 24 hours, load is decreased gradually (100\%- 75\%- 50\%- 25\% - 0\%)

$>$ each released stage is held for 1 hour, and after releasing all load it must held for 24 hours.

The load test for the roof slabs and beams results as follows Figure 14 and Table 8: 

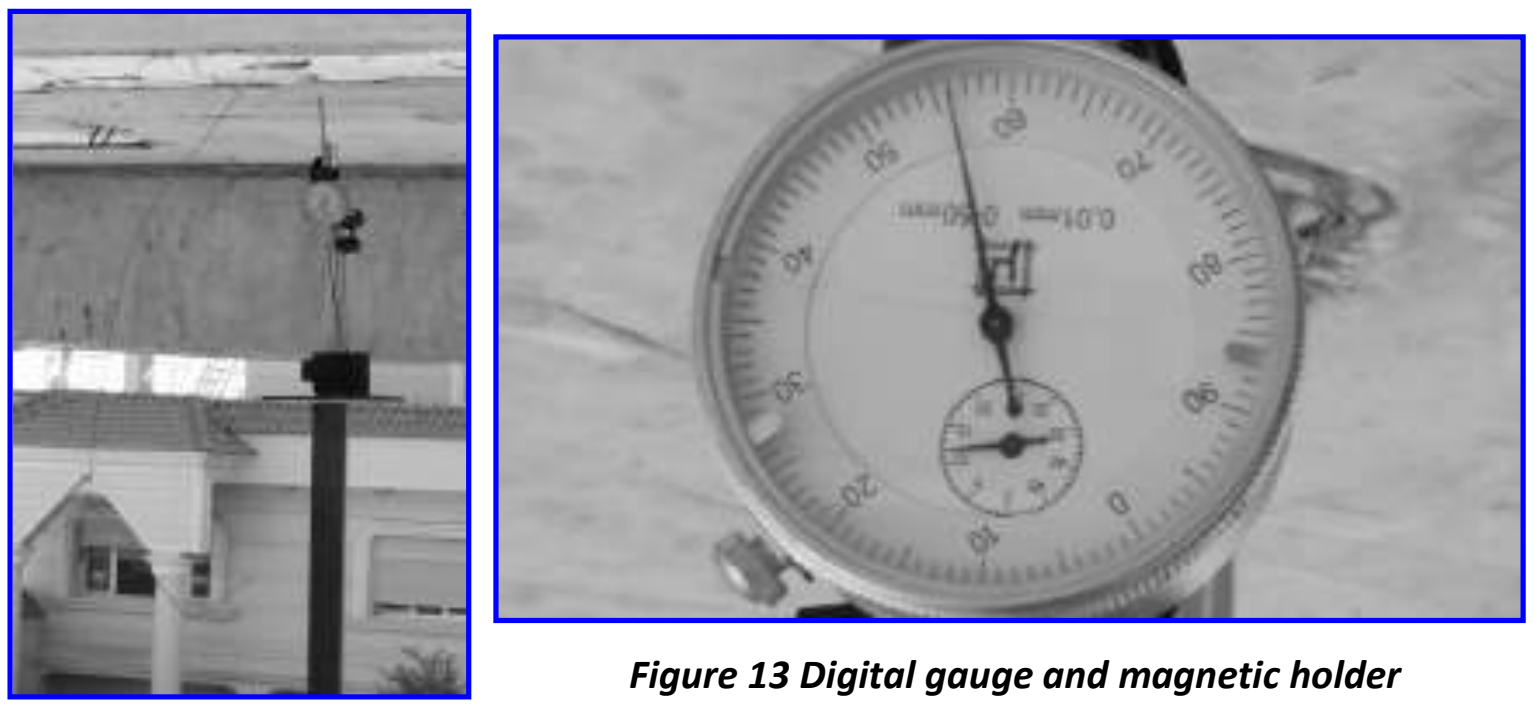

Figure 13 Digital gauge and magnetic holder

(The load test was carried out by the Government Inspection Center of the Ministry of

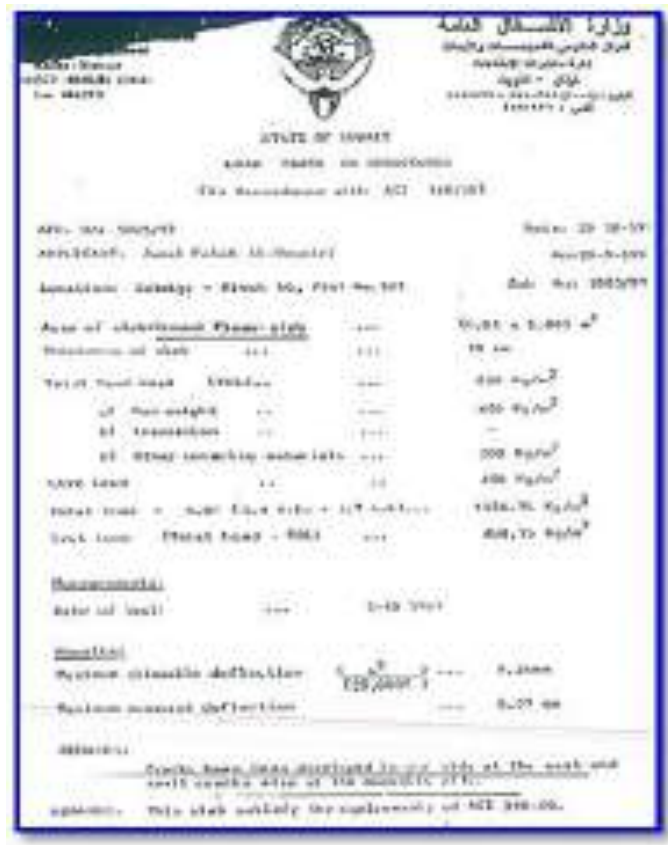

Public Works-Kuwait)

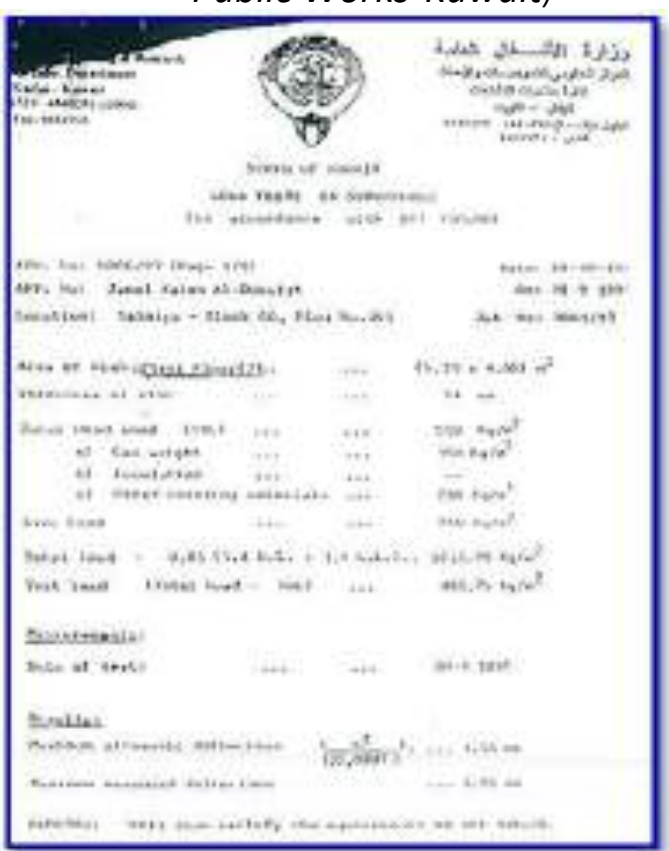

Figure 14 Ministry of Public work inspection reports

Table 8. Analysis of load test results

\begin{tabular}{|c|c|c|c|c|}
\hline No & Statement & Slab1 & Slab2 & Slab3 \\
\hline 1 & Identification of the specimen \&Location & S5 & S8 & S9 \\
\hline 2 & Dimensions $(\mathrm{m})$ : & $6.05 * 5.80$ & $5.25 * 4.60$ & $4.50 * 4.00$ \\
\hline 3 & Thickness $(\mathrm{cm})$ : & 18 & 14 & 14 \\
\hline 4 & Dead Load :1) Own Weight $\left(\mathrm{Kg} / \mathrm{m}^{2}\right)$ & 450 & 350 & 350 \\
\hline 5 & 2)Covering Load (Finishing) $\left(\mathrm{Kg} / \mathrm{m}^{2}\right)$ & \multicolumn{3}{|l|}{200} \\
\hline 6 & Total Dead Load (TDL) $\left(\mathrm{Kg} / \mathrm{m}^{2}\right)$ & 650 & 550 & 550 \\
\hline 7 & Live Load $\left(\mathrm{Kg} / \mathrm{m}^{2}\right)$ & \multicolumn{3}{|l|}{250} \\
\hline 8 & Total Load $\left(\mathrm{Kg} / \mathrm{m}^{2}\right)=0.85 \times(1.4 \mathrm{D} . \mathrm{L}+1.7 \mathrm{~L} . \mathrm{L})$ & 1134.75 & 1015.75 & 1015.75 \\
\hline 9 & Test Load =Total Load - TDL $\left(\mathrm{Kg} / \mathrm{m}^{2}\right)$ & 484.75 & 465.75 & 465.75 \\
\hline 10 & Max. Allowable Deflection $=\mathrm{L}^{2} / 20000 * \mathrm{~T}(\mathrm{~mm})$ & 9.34 & 5.7 & 7.56 \\
\hline 11 & Max. Measured Deflection (mm) & 8.27 & $\underline{5.05}$ & $\underline{6.95}$ \\
\hline 12 & Remarks: This slab as Requirement of $\mathrm{ACl}-318$ & Satisfy & Satisfy & Satisfy \\
\hline
\end{tabular}


After the test, cracks have been developed in one side and smaller one at opposite side. Deflection values that occurred after the tests was acceptable according to the $\mathrm{ACl}-318$ code. The ratio of the existing reinforcing steel is greater than the maximum percentage, it indicates that the concrete strength will reach its maximum value before the steel reaches to the yield point.

\section{Second Case Identification of damage causes:}

According to drawing design, and core test and load test analysis for the concrete, with reference to the nature of the damage and its shape. Damage causes can be summarized as follows:

4.1. Concrete is Non-conforming to the required specifications in the roof slabs.

4.2. Poor roofs slabs implementation, where thickness of many slabs does not match the drawings, causing distortions and large cracks in slabs.

4.3. Poor installation of steel bars, where the required distances between the bars were not considered, which led to a weak link between the concrete and steel, where voids occurred in concrete.

4.4. Lack of sufficient concrete cover for many structural elements

4.5. Un satisfactory fitting of air-conditioning openings, especially in the high cut points of beams.

\section{Methods of treatment and repair:}

5.1. Due to the weak of concrete and many cracks in the slabs of the ground and first roof, it must be demolished and re-poured, with proper reinforcement procedures that extend to adjacent slabs.

5.2. Strengthening the identified beams, using appropriate steel section, and strong adhesive materials like (epoxy materials).

5.3. Reinforcing the defected columns with appropriate steel sections.

5.4. Apply epoxy layer to the old concrete faces where they are bonded with the new concrete before casting directly [15].

\section{Conclusions and Recommendations:}

This paper presented methods to evaluate Structural Strength, using Load and Core Tests, it also present methods to analysis the Causes of Structural Strength failure: based on the results obtained from the tests, site investigation, and structural design drawing. For the two vacant villas, structure strength tests were conducted, and data has been analysis. As a result, Core test and the load test in-situ prove that the $\mathrm{ACl}-318$ code gives logical results and expressive status, for structural component strengths. The causes of weak slabs and beams resulted from weak of design and defect in implementation. The tests showed that the concrete slabs were more elastic as the recovery deflection was relatively large compared to the initial deflection. quality control and weak audit of these designs. Failure to fulfill the requirements and specifications of the international codes and feeble monitoring, neglection to apply technical conditions, and weak Supervision on the construction site, was the main causes to failure in the structure.

In the first building (Bayan), beams should be supported by steel beams to support the structure to withstand the loads. Cracks should be repaired by epoxy products. The second building (Salmiyah), slabs (S5, S8, S9) should be demolished and recasting concrete accordance to $\mathrm{ACl}-318$ specifications. 


\section{References}

[1]. Tuncan, M., et al., Assessing concrete strength by means of small diameter cores. Construction and Building Materials, 2008. 22(5): p. 981-988.

[2]. ASTM, C., 42/C 42M-90. Test for obtaining and testing drilled cores and sawed beams of concrete, Annual Book of ASTM Standards, 2008.

[3]. Nikbin, I., M. Eslami, and D. Rezvani, An experimental comparative survey on the interpretation of concrete core strength results. Eur J Sci Res, 2009. 37(3): p. 445-456.

[4]. Gibbs, J. and W. Zhu. Strength of hardened self-compacting concrete. in Proceedings of First international RILEM Symposium on Self-Compacting Concrete (PRO 7), Stockholm, Suede. 1999.

[5]. Khoury, S., A.A.-H. Aliabdo, and A. Ghazy, Reliability of core test-Critical assessment and proposed new approach. Alexandria Engineering Journal, 2014. 53(1): p. 169-184.

[6]. Friedman, D., Historical building construction: design, materials, and technology. 2010: WW Norton \& Company.

[7]. Galati, N., et al., In-situ evaluation of two concrete slab systems. I: Load determination and loading procedure. Journal of Performance of Constructed Facilities, 2008. 22(4): p. 207-216.

[8]. Goble, G.G., Geotechnical related development and implementation of load and resistance factor design (LRFD) methods. Vol. 276. 1999: Transportation Research Board.

[9]. Galati, N. and T. Alkhrdaji, In Situ Evaluation of Structures Using Load Testing, in Forensic Engineering 2009: Pathology of the Built Environment. 2010. p. 657-667.

[10]. Mettemeyer, M. and A. Nanni, CENTER FOR INFRASTRUCTURE ENGINEERING STUDIES.

[11]. Luping, T. and L.-O. Nilsson, Rapid determination of the chloride diffusivity in concrete by applying an electric field. Materials Journal, 1993. 89(1): p. 49-53.

[12]. Ridge, A.R. and P.H. Ziehl, Evaluation of strengthened reinforced concrete beams: cyclic load test and acoustic emission methods. ACI Structural Journal, 2006. 103(6): p. 832.

[13]. Abdulahad, E., Developing a national system for the investigation of the structures in Symposium of the Bulgarian construction chamber Bulgaria. 2014: Sofia ,Bulgaria

[14]. Illidge, F.A.B., Acoustic emission techniques and cyclic load testing for integrity evaluation of self-compacting normal and self-compacting lightweight prestressed concrete girders. 2010, University of South Carolina.

[15]. Abdulahad, E., Essence and issues affecting the operation of the National Service of operational reliability, in Symposium of the Bulgarian construction chamber Bulgaria 2014: Sofia Bulgaria

[16]. Committee, A., A.C. Institute, and I.O.f. Standardization. Building code requirements for structural concrete (ACl 318-08) and commentary. 2008. American Concrete Institute.

[17]. Committee, A., Building code requirements for structural concrete (ACl 318-14) and commentary. ACl, Farmington Hills, United States, 2014.

[18]. ACl Committee 318, American Concrete Institute, , Building Code Requirements for Structural Concrete and Commentary, (ACl 318-95). 1995, 